\title{
REVIEW
}

\section{Economic Effects of Climate Change in Alaska $\mathscr{O}$}

\author{
MATTHEW BERMAN AND JENNIFER I. SCHMIDT \\ Institute of Social and Economic Research, University of Alaska Anchorage, Anchorage, Alaska
}

(Manuscript received 6 June 2018, in final form 19 November 2018)

\begin{abstract}
We summarize the potential nature and scope of economic effects of climate change in Alaska that have already occurred and are likely to become manifest over the next 30-50 years. We classified potential effects discussed in the literature into categories according to climate driver, type of environmental service affected, certainty and timing of the effects, and potential magnitude of economic consequences. We then described the nature of important economic effects and provided estimates of larger, more certain effects for which data were available. Largest economic effects were associated with costs to prevent damage, relocate, and replace infrastructure threatened by permafrost thaw, sea level rise, and coastal erosion. The costs to infrastructure were offset by a large projected reduction in space heating costs attributable to milder winters. Overall, we estimated that five relatively certain, large effects that could be readily quantified would impose an annual net cost of $\$ 340-\$ 700$ million, or $0.6 \%-1.3 \%$ of Alaska's GDP. This significant, but relatively modest, net economic effect for Alaska as a whole obscures large regional disparities, as rural communities face large projected costs while more southerly urban residents experience net gains.
\end{abstract}

\section{Background}

\section{a. Economic effects of climate change in Alaska}

High northern latitudes are warming much faster than more temperate zones. Alaska has warmed more than twice as rapidly as the rest of the United States (Taylor et al. 2017), with statewide average annual air temperature increasing by $1.5^{\circ} \mathrm{C}$ and average winter temperature by more than $3^{\circ} \mathrm{C}$ since the 1950 s (Walsh et al. 2014) A series of synthesis reports have documented and summarized a wide range of effects of recent and projected warming on the physical environment, ecosystems, and human activities (ACIA 2004; Larsen and Fondahl 2014; Chapin et al. 2014; Hovelsrud et al. 2011; Larsen et al. 2014). Although these effects of a warming climate are bound to have consequences for the economy, considerably less is known specifically about the economic effects.

We addressed this information gap by describing the potential nature and scope of economic effects of climate

Supplemental information related to this paper is available at the Journals Online website: https://doi.org/10.1175/WCAS-D-18-0056.s1.

Corresponding author: Matthew Berman, matthew.berman@ alaska.edu change that have already occurred and are likely to become manifest in Alaska over the next 30-50 years. We compiled effects arising through a broad spectrum of drivers and mechanisms using a common framework and divided potential economic effects into categories according to a number of criteria. We begin by briefly reviewing the mechanisms by which global climate change generates local and regional economic effects and how much regional warming is anticipated. We then discuss our approach to classify economic consequences of climate change impacts discussed in the literature. Next, we present the results of the classification and provide preliminary impact estimates, along with data sources and assumptions, of the subset of economic effects identified as relatively large and certain. A discussion section places the economic effects in the context of Alaska's economy, noting important regional disparities, primary uncertainties, and known data gaps. The conclusion discusses implications of the regional disparities for adaptation policy.

\section{b. How global climate change generates local economic effects}

Alaska's economy is primarily based on natural resource extraction; federal, civilian, and military spending; and tourism (BEA 2018; Goldsmith 2010; 


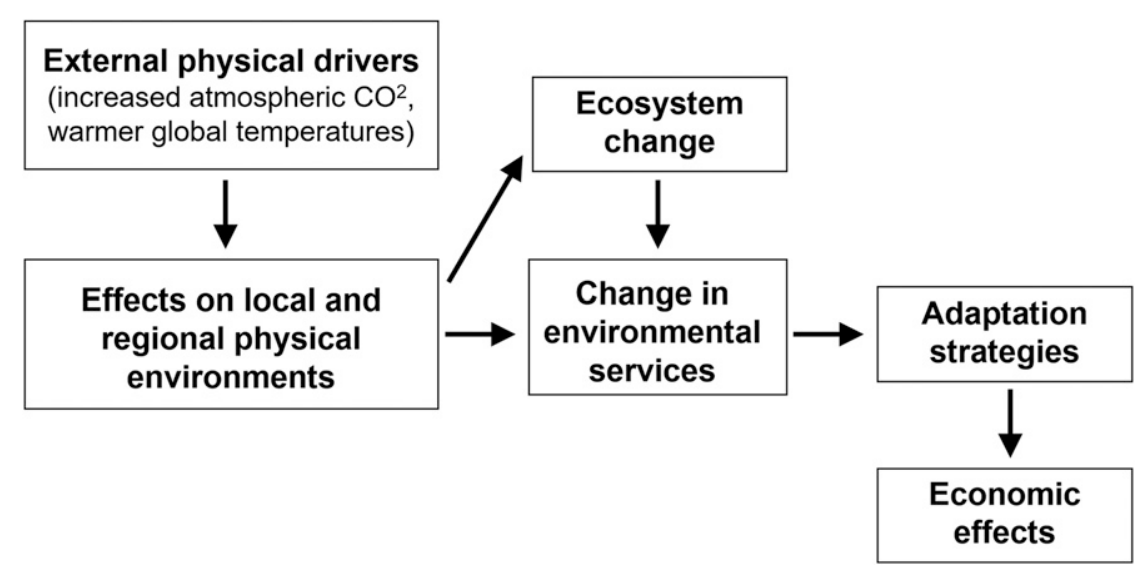

FIG. 1. Schematic for how global climate change generates local economic effects.

McDowell 2016). Oil production, commercial fishing, and nature-based tourism are particularly important and potentially affected by climate change. Many residents of rural Alaska engage in a local mixed economy, balancing wage employment with subsistence hunting and fishing activities (Goldsmith 2007) that are also vulnerable to environmental change (IPCC 2007; Markon et al. 2012). However, as we note below, many of the most important economic consequences of climate change affect infrastructure and living conditions for the resident population and are not tied to any particular economic sector.

Rising global temperatures and changes in precipitation have been linked to a variety of effects on Alaska's regional physical environments (Fig. 1), including warmer, longer summers; shorter, milder winters (Stewart et al. 2013; Wendler and Shulski 2009; Wendler et al. 2012); increased precipitation (Stewart et al. 2013); melting cryosphere and glaciers (Berthier et al. 2010; Jacob et al. 2012); thawing of the cryosphere and permafrost (ACIA 2004; Avis et al. 2011; Jafarov et al. 2012; Romanovsky et al. 2008); rising sea levels (Nicholls et al. 2007); and more varied and stormy weather (Pisaric et al. 2011; Terenzi et al. 2014; Vermaire et al. 2013). The shrinking of the cryosphere due to warming temperatures is already causing a variety of changes to Alaska's marine and terrestrial ecosystems (ACIA 2004). Glacial melt affects availability of phosphorus, iron, and organic carbon to marine organisms (Hood and Scott 2008; Hood et al. 2009; Schroth et al. 2011). Warmer ocean temperatures and circulation relocate suitable habitats for marine species (Barbeaux et al. 2017; Cheung et al. 2009; Stabeno et al. 2005). Changes in timing of the onset of seasonally warm and cold temperatures change bird migration patterns (Hezel et al. 2012). Warmer and drier conditions lead to increased insect damage to forests (Berg et al. 2006; Gordon et al. 2013; Wolken et al. 2011) and more frequent and intense wildfires (Calef et al. 2015). In turn, the changes in fire and insect regimes may accelerate the spread of invasive species (Cortés-Burns et al. 2008; Lapina and Carlson 2004), spread brush and trees to formerly treeless landscapes (Jia et al. 2003; Sturm et al. 2001), and cause dominant forest vegetation to shift from spruce to broadleaf trees (Barrett et al. 2011; Johnstone et al. 2011).

These profound and diverse changes in the physical environment and ecosystems generate economic effects through their effects on environmental services (ES; United Nations 1997). We use ES instead of the more widely used term "ecosystem services"the products of ecosystems that people value (Reid et al. 2005)-because ES include benefits people derive directly from the physical environment as well as from ecosystems. As Fig. 1 illustrates, some changes in ES result directly from changes in the physical environment (e.g., temperature moderation, stable ground supporting infrastructure, smooth surface for transportation), while others arise indirectly from effects on ecosystems of changes in the physical environment.

We ignore potentially large global effects of Arctic warming (Hope and Schaefer 2016) and focus instead on local and regional effects. Economic effects of changes in ES include use and nonuse values. Nonuse values, such as existence value, are difficult to define precisely and even more difficult to estimate. We therefore focus this study on use values. Acknowledging the critical importance of cultural services to many Alaskans, we exclude cultural effects from our definition of economic effects, except for market-based economic activity related to recreation and tourism. 


\section{c. Assumptions for warming}

The 30-50-yr time horizon for the analysis corresponds to the longest time frame generally used for planning long-term investment decisions, such as to construct new housing and commercial buildings, develop resource deposits, and build public infrastructure. We use the scenarios for warming included in the third U.S. National Climate Assessment (NCA), which projects that average annual temperatures in Alaska will rise by an additional $1^{\circ}-2^{\circ} \mathrm{C}$ by 2050 , regardless of greenhouse emission trajectories (Walsh et al. 2014). More recent projections for the fourth NCA (Hayhoe et al. 2017; Taylor et al. 2017) appear quite similar to those of the third NCA, but include less detail for Alaska. As a rough guide, the projections suggest that the economic effects of warming over the next 30-50 years will equal or exceed what has occurred over the past 50 years. That said, we acknowledge and note below that some changes may cross tipping points, with potentially large ramifications. Since climate change is already underway in Alaska, the economic effects of climate change are cumulative effects, including effects of warming that has already occurred. Although projections past 2050 are much less certain, Alaska is likely to warm by $3^{\circ}-4^{\circ} \mathrm{C}$ in the north and $2^{\circ}-3^{\circ} \mathrm{C}$ in the rest of the state by the end of the century, even with substantial emissions reductions (Walsh et al. 2014).

\section{Methods}

We take a multidimensional approach consistent with Arent et al. (2014) to summarize what is known with differing levels of certainty about the direction and magnitude of the potential economic effects. The first step is to enumerate projected effects of climate change on land and marine temperatures, the cryosphere, wildfire regimes, and terrestrial and marine ecosystems that are likely to affect human activities. We use the U.S. National Climate Assessment-Alaska Regional Technical Report (Markon et al. 2012) as a starting point to identify potential environmental impacts, adding information from other relevant studies. We then describe potential economic consequences of these changes in the physical environment and ecosystems in qualitative terms. While the list of potential effects is long, it is likely incomplete.

Potential changes in ES affect people in diverse ways. The climate impacts literature describes and projects economic effects in a variety of ways, without a "common yardstick" to assess relative or overall significance, creating a challenge for comparative studies. The problem is further complicated by the fact that few studies in the large body of literature on potential effects of climate change in Alaska provide enough detail about the climate and socioeconomic scenario assumptions they used. This makes it difficult to adjust the projected effects and perform comparisons with effects drawn from other studies. The ability to generate a total figure for the cost of climate change in Alaska is limited to what is feasible, given what is known about effects that can be quantified with some level of precision. We proceed toward the goal of assessing overall significance in several steps. First, we organize and evaluate potential economic effects by classifying impacts described in the literature along eight criteria, or dimensions:

1) Physical and ecological drivers.

2) Effects on ES.

3) Level of certainty of ES effects.

4) Timing of ES effects.

5) How ES change affects the economy.

6) Magnitude of economic effects.

7) Sector most affected (households, businesses, or the public sector).

8) Distribution of economic effect (i.e., change in economic activity, change in business profits, change in cost of living, change in cost of government).

Some effects are relatively assured and, in some cases, are already occurring. Other impacts are highly uncertain, due to their dependence on the structure of global and regional economies and future human alterations to the environment decades into the future. We classify potential economic effects of the changes in ES by high, medium, and low levels of certainty, based on the certainty expressed in publications describing the effects, and the level of agreement among studies. Highly uncertain effects are those for which several publications agree that large uncertainty exists, or for which publications draw several or opposite conclusions about the effects of regional warming. More certain effects are ones for which the science directly ties ES changes to warming or greenhouse gas emissions, and for which local economic effects are measurable and can be distinguished from effects of other forces of change.

We use three size categories to classify magnitude of effects. Large economic effects are likely to have an annual (real, undiscounted) impact of $\$ 50$ million or greater. Small economic effects would likely have an impact of less than $\$ 5$ million annually, while medium effects would be in the $\$ 5-\$ 50$ million range. The size categories are broad - meant only to identify effects that most warrant further analysis-because information to assess magnitude of effects is often sparse. Where information about costs was lacking, we inferred order-ofmagnitude economic activity associated with changes in ES by applying the authors' professional judgment and understanding of the structure of the Alaska economy. 
One case involves activities that could theoretically benefit from warming, but whose expansion is currently limited by nonclimate factors (e.g., commercial agriculture). Another case involves activities with available close substitutes for a climate-affected ES, keeping the net cost low. In still other cases, the economic effect may be potentially large, but realized primarily outside Alaska. Most of the economic effect of an increase in marine shipping through Arctic waters, for example, would likely occur in the Russian sector rather than along Alaska's coasts, due both to likely patterns of trade and availability of deep-water ports.

From the classification results, we select economic effects for quantification. These are effects that are more certain, already occurring or likely to occur in the relatively near term, readily quantified, and can be measured appropriately in financial terms. We estimate dollar values for this subset of effects to the extent data are available. Methods vary for each effect and are summarized with the presentation of results. As projected effects occur decades from now, one must make assumptions about discounting of future costs. Different studies in the literature applied different discount rates across differing time horizons. To standardize figures from studies using disparate assumptions, we converted values projected in each study to annual average effects in constant 2015 U.S. dollars, applying the discount rate and time horizon used in that particular study. We also discuss qualitatively the nature of potential economic effects that are not appropriately measured in financial terms such as subsistence harvests. For all effects including those discussed only qualitatively, we indicate the direction of effects, their sensitivity to climate change, and the relative influence of climate versus other drivers of change.

We use the gross domestic product (GDP) accounting framework to quantify effects. Climate-related costs in the GDP framework represent losses of real national value added due to climate change. Projected changes in value added depend on future prices of goods traded in global markets. World market prices are highly uncertain and could change due to various factors operating outside Alaska, including climate impacts in other regions. Since too many uncertainties are present to make reliable projections of relative prices of different products and services, we project annual average values using constant 2015 prices.

The market value added metric of GDP accounting, although widely used, contains several well-known limitations. The basic flaw is that not all economic effects of climate change are measurable in value added terms. Some costs to the nation may not appear as a loss to the Alaskan economy and may even show up as an increase in Alaskan value added if most of the costs are paid by households, businesses, or taxpayers in other states. To capture all the relevant effects, we describe separately five categories of effects for households, businesses, and the public sector:

- Change in value added in Alaska (value of shipments less cost of inputs purchased from outside Alaska) for specific industries.

- Change in household cost of living.

- Change in purchased input costs for businesses and governments.

- Change in nonwage benefit flows to households, including subsistence benefits.

- Change in value of buildings and infrastructure. ${ }^{1}$

The actual economic effects of climate change depend on individual and collective decisions for adapting to the changes in ES. We note where inferred effects depend on assumptions about adaptation decisions and how different assumptions might produce different results, when these assumptions may be determined in the studies we review.

\section{Results}

\section{a. Summary of economic effects by industry or sector}

Appendix A in the online supplemental material contains the detailed results of classification of economic effects by climate driver, environmental service affected, size and level of certainty, and how the effects are distributed through the economy. Here, we summarize the various effects by industry or sector experiencing the economic impact.

\section{1) HYDROPOWER}

Melting glaciers (Berthier et al. 2010; Jacob et al. 2012) will increase the role of seasonal precipitation patterns in determining hydroelectric capacity. River discharge has been increasing during the winter since the 1960s, but shows no trends in other seasons (Cherry et al. 2010). Because reservoirs are generally full in fall, investments to increase reservoir heights would be required to take advantage of increased fall precipitation. Insufficient connectivity between locations and capacity to share surplus power limits hydropower security more than climate change risks (Cherry et al. 2010).

\footnotetext{
${ }^{1}$ For comparison with other impacts, one could amortize the change in asset values into annual flows over the life of the asset. Since it is not common practice in GDP accounting to convert capital gains and losses into annual flows of value added, we list changes in asset values and changes in value added as separate effects.
} 


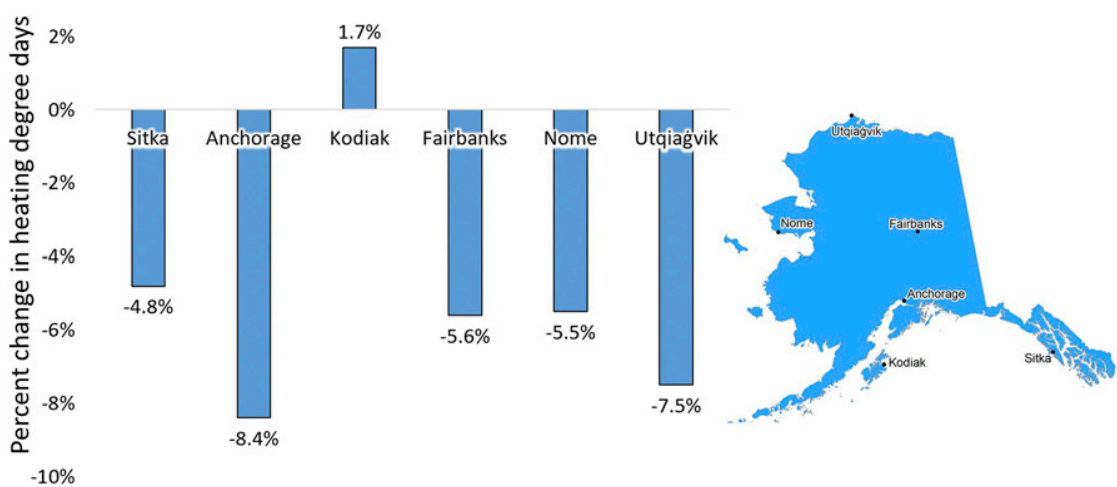

FIG. 2. Percentage change in annual HDDs, 2000-15 vs 1950-79. (Source: NWS daily weather summaries.)

\section{2) TOURISM AND RECREATION}

The Modified Climate Index for Tourism (MCIT) for King Salmon and Anchorage showed an increase in season length for sightseeing, but no improvement in seasonal weather quality ( $\mathrm{Yu}$ et al. 2009). Shorter winter seasons in south-central Alaska reduce sales for snow sport businesses and increase snow-making costs for ski areas, offset in part by an increase in quality because of fewer extremely cold days. A projected increase in rainy weather would discourage marine trips and hiking expeditions in southeast Alaska (Colt et al. 2007; Gregory et al. 2006). Because the effects on tourism and recreation are complex and nuanced, additional studies using detailed operator data are needed to determine net effects.

\section{3) ENERGY DEMAND}

Warming winter temperatures have reduced the demand for energy and associated costs to provide space heating for Alaskan homes, businesses, and governments. National Weather Service (NWS) daily weather data show that heating degree-days (HDD) have declined substantially in most parts of the state from historical levels (Fig. 2). Although Anchorage had the largest percentage of HDD decline between 1950-79 and $2000-15$, the absolute change was largest in Utqiagvik (Barrow; 1529 fewer annual HDDs). Since 1979 , temperatures in Utqiagivik have increased $3.8^{\circ} \mathrm{C}$ in September, $6.6^{\circ} \mathrm{C}$ in October, and $5.5^{\circ} \mathrm{C}$ in November (Wendler et al. 2014). Increased cooling degree-days (CDD) from warmer summer temperatures provide only a small offset to the beneficial effect of lower heating costs. NWS data show that CDD increased from an annual average of 2 to 7 between 1950-79 and 2000-15 in Anchorage, and from 50 to 59 in Fairbanks. Average annual CDD in the other sites listed in Fig. 2 were small $(\leq 3)$ and essentially unchanged.

\section{4) Agriculture}

The growing season increased by $45 \%$ in interior Alaska over the twentieth century (Wendler and Shulski 2009). That trend is expected to continue (Chapin et al. 2014), which will increase the feasibility of agricultural activities within the state. Since northern areas in Canada and Russia are experiencing a similar climate benefit for agriculture and are geographically much larger and generally closer to large market opportunities, it is unlikely that Alaska's agricultural exports will expand significantly over the next several decades. Instead, an increasing but still small share of food consumed by Alaska's residents may be grown locally, with a slight increase in food security (Meter and Phillips 2014; USDA 2017). Farm incomes will rise, and more businesses will be selling inputs to local gardening and food production, but the total effect is likely to be relatively small.

\section{5) FORESTRY}

Decreased soil moisture (Chapin et al. 2014) and lack of cold winter temperatures are associated with increased insect activity that has reduced growth and density of white spruce (picea glauca) and changed forest composition (Wolken et al. 2011). Timber production in interior regions could decline, but from a relatively small base (Barber et al. 2000; Beck et al. 2011). An increase in birch firewood may potentially offset the reduction in spruce, although the species composition of future interior Alaskan forests under a warmer climate is not known (Euskirchen et al. 2009; Juday et al. 2005).

\section{6) FISHING}

Warming ocean temperatures and shifts in coastal currents have already changed marine ecosystems and the fisheries they support (Barbeaux et al. 2017; Fellman 
et al. 2010; Hood et al. 2009; Royer and Grosch 2006). Some commercial fisheries have shifted location; some have declined, while others have expanded. Overall, the changes have increased uncertainty in the fishing industry. Ocean acidification-not a climate change effect per se, but also driven by atmospheric carbon dioxide concentrations-adds to the uncertainty of future commercial fishing in Alaska. Mathis et al. (2014) concluded that risks to coastal fisheries and fishing communities were high in southeast and southwestern Alaska. However, not enough is known about the effects of acidification on specific harvested or harvestable species to assess the economic effects.

\section{7) INDUSTRY AND PUBLIC INFRASTRUCTURE}

Threats to infrastructure from coastal and riparian erosion caused by the combination of rising sea levels, thawing permafrost, reduced sea ice, and fall storms are well known (Alessa et al. 2008; Hong et al. 2014; Raynolds et al. 2014; White et al. 2007). The U.S. Army Corps of Engineers identified erosion threats to 31 communities, including seven (Bethel, Dillingham, Kaktovik, Kivalina, Newtok, Shishmaref, and Unalakleet) requiring partial or complete relocation (USACE 2009). The Corps projected that Kivalina, Newtok, and Shishmaref may start losing critical infrastructure to erosion as early as 2020 .

Thawing permafrost is also causing widespread and accelerating damage to public infrastructure not at risk from erosion (Larsen et al. 2008; Melvin et al. 2017a; USEPA 2017). Economic effects include shortened useful life of buildings, additional maintenance and repair costs, as well as early reconstruction and replacement. In addition to imposing costs to repair or replace infrastructure, rupture of water and sewer lines may temporarily displace residents, contaminate drinking water, and impose other less tangible costs (Agnew Beck Consulting 2012; USACE 2008a,b) that increase risks to public health (Brubaker et al. 2011; Gregory et al. 2006).

In rural Alaska, where surface transportation infrastructure is extremely limited, snow and ice offer a low-cost alternative for moving people, goods, and heavy industrial equipment. The shorter and milder cold season reduces the season length for ice road use, increases risk of travel on river ice, and increases wear and tear on snow machines. Some of the economic consequences of the loss of overland winter transportation come in the form of higher costs for extractive industries and rural Alaskan households, but other effects such as foregone economic activity (Hinzman et al. 2005) and increased risk of winter travel are more difficult to quantify (Reimchen et al. 2009).

\section{8) MARine AND COASTAL SHIPPING}

Melting of sea ice sufficient to open the Northwest Passage could reduce the distance shipping to or from North America by 30\% (Smith and Stephenson 2013). Although shipping activity will undoubtedly increase, significant effects are likely several decades off. Most of the new shipping will not touch Alaska's shores, but merely transit between Pacific and Atlantic temperate zone ports, although the increase in traffic will bring environmental risks to subsistence resources (Huntington et al. 2015). Theoretically, the increased marine transportation could increase resource exploitation and tourism (Larsen and Fondahl 2014; Arctic Council 2009). New oil and gas exploration and development in the U.S. economic zone is unlikely, though, as the Arctic Ocean waters that are not already accessible are generally off the continental shelf. Lack of deepwater ports and vessel services and search and rescue, environmental response, and icebreaking capacity will impede expansion of vessel traffic (Arctic Council 2009; Azzara et al. 2015; Bensassi et al. 2016; Eguíluz et al. 2016). It is unclear to what extent the potential expansion of Arctic Ocean cruises would constitute new visitors to Alaska or merely redistribute existing visitors from southeast and south-central Alaska.

A longer ice-free shipping season could reduce the cost of barge service to communities in western and northern Alaska. It could reduce the cost of shipping ore from the Red Dog mine and other mines in the region (Arctic Council 2009), as well as increase certainty of shipping production facilities and equipment to North Slope oil fields. Potentially offsetting the beneficial effect of warming on barge service to Alaskan communities from less ice is the effect on reduced river discharge. Many communities along rivers are facing reduced barge service because rivers are becoming too shallow, which could dramatically increase fuel costs to residents (National Research Council 2014).

\section{9) Subsistence}

A full discussion of effects of climate change on subsistence is beyond the scope of this paper. We note, however, that effects on subsistence-systems of production, distribution, and consumption based on household production (Wolfe and Walker 1987) - are economic effects. Climate change is already causing a variety of changes in subsistence harvest cycles, including changes in important food sources (Kofinas et al. 2010; Nelson et al. 2008), loss of some locations used for fishing and waterfowl hunting, and gain of other locations (Chapin et al. 2014; Scott et al. 2008). The largest negative effects stem from melting sea ice and 
associated ecological change in western and northern Alaska (Hezel et al. 2012; Huntington et al. 2016). Shrinking seasonal sea ice cover and shifting weather patterns increase the risk of travel in small boats and reduce the time period when walrus and other sea icedependent species are available for harvesting. The inability to predict water temperature, turbidity, and wind for fish harvest activities and the potential decline in marine mammal harvests increases uncertainty of subsistence food harvests, reducing food security (Gregory et al. 2006).

\section{0) Public Safety}

Warming summers have driven an increase in wildfire frequency and area burned over the past two decades (Kelly et al. 2013). Expanding roads and areas with human settlement over the same period has led to an increase in human-caused ignitions, which now account for nearly half of fire starts in Alaska (DeWilde and Chapin 2006). On the Kenai Peninsula, perception of increased fire danger associated with trees killed by bark beetles (Gordon et al. 2013) aligns with similar perceptions outside of Alaska (Hicke et al. 2012; Jolly et al. 2012). Increasing fires near inhabited areas leads to a wide array of costs, including higher firefighting costs, health and safety impacts, property damage, insurance losses, and, in the long run, higher costs of fire insurance for homeowners and businesses (Trainor et al. 2009). In addition, tourism businesses may experience short-term losses if visitors avoid recently burned areas.

\section{b. Quantification of important effects}

Some of the economic effects summarized above clearly have larger consequences for the economy than others, either because they affect more people or a larger portion of the economy, or because they have a greater impact on the portion of the economy that they do affect. Some of these potentially important effects, however, are highly uncertain. Here, we discuss quantification of the effects that are both highly likely to occur and could have a medium or large economic effect.

We measure direct effects of changes in ES occurring in Alaska, including changes in value-added and living costs, that may be inferred from the information available. One could apply a spending multiplier to these direct effects for a small open economy like Alaska's or use an input-output table to estimate indirect impacts on the state's GDP. However, these secondary multiplier effects largely represent a transfer of spending between Alaska and the rest of the United States, so they should not be considered net effects from a national perspective.

\section{c. High certainty, large effect}

\section{1) INFRASTRUCTURE DAMAGE DUE TO PERMAFROST THAW AND COASTAL EROSION}

One study estimated that the cost from 2006 to 2030 of damage to public infrastructure by thawing permafrost, flooding, and coastal erosion in Alaska was between $\$ 3.6$ and $\$ 6.1$ billion in 2008 dollars (Larsen et al. 2008). This cost was associated with shortened useful life of buildings, requiring early reconstruction and replacement. Assuming the $2.85 \%$ annual real interest rate used in that study, the cost translates to an average annual cost of \$250-\$420 million in 2015 dollars over the same time period. A more recent estimate using similar methodology (USEPA 2017) estimated infrastructure maintenance and repair costs to mitigate or remediate damage from climate warming to the end of the century of \$3.7-\$4.5 billion, depending on the climate change scenario. However, proactive adaptation measures could reduce that cost to $\$ 2.0-\$ 2.5$ billion. This estimate of cumulative effects would be associated with a somewhat smaller annual cost of $\$ 110-\$ 270$ million between 2015 and 2060 (Melvin et al. 2017a). Because federal grants are available to build and replace facilities, while maintenance and repair costs must be financed locally, public infrastructure maintenance is chronically underfunded in Alaska, especially in rural areas where infrastructure is most at risk to permafrost thaw damage (Colt et al. 2003; Hope and Schaefer 2016). This institutional reality makes the larger figures based on shortened useful life of buildings a more reliable estimate of projected costs to society. Both studies addressed only costs for Alaska's public road, building, airport, rail, and pipeline infrastructure, and excluded commercial and industrial buildings and private homes. They also excluded losses associated with lack of access to utilities and drinking water, temporary displacement of residents when water and sewer lines rupture (Agnew Beck Consulting 2012; USACE 2008a,b), and associated costs of increased risks to public health (Brubaker et al. 2011; Gregory et al. 2006).

\section{2) COMmunity RelocAtion}

Coastal erosion and flooding in some cases will require that entire communities, or portions of communities, relocate to safer terrain. Relocation costs for seven vulnerable communities identified in a 2009 U.S. Government Accountability Office (GAO) study ranged from $\$ 80$ to $\$ 200$ million per community (GAO 2009). The state of Alaska recently requested $\$ 162.4$ million from Congress for three such communities damaged by erosion and flooding that the U.S. Army Corps of 
TABLE 1. Estimated energy use and cost for space heating in Alaska, 2012. [Source: Calculated by authors from data presented by WHPacific (2012) and Alaska Division of Community and Regional Affairs Community Fuel Price Survey (https://www.commerce. alaska.gov/web/dcra/researchanalysis/fuelpricesurvey.aspx).]

\begin{tabular}{lccr}
\hline \hline & Energy used (million MMBtu) & Average cost of energy (\$ per MMBtu) & Space heating cost (\$ million) \\
\hline Residential & 50.4 & $\$ 13.78$ & $\$ 695.8$ \\
Nonresidential & 18.4 & $\$ 17.69$ & $\$ 325.9$ \\
Total & 68.8 & & $\$ 1,020.7$ \\
\hline
\end{tabular}

Engineers determined need to be completely relocated within the next 10-15 years (Associated Press 2015). Construction of rock walls, sandbags, riprap (State of Alaska 2010), and replacement infrastructure for communities that are partially relocated (USACE 2009) represent additional costs. Including costs associated with protecting, reinforcing, and relocating infrastructure, $\$ 50-\$ 100$ million per year represents a reasonable projection of costs to protect infrastructure threatened by erosion and move communities to safer ground.

\section{3) Space heAting}

Reduced space heating demand represents an important positive effect of climate warming. Data from the 2012 Alaska Energy Authority energy end-use study (WHPacific 2012) show that Alaskans annually use about 50 million MMBtu to heat residential homes and 18 million MMBtu to heat nonresidential space heating (i.e., commercial and industrial buildings and public infrastructure). ${ }^{2}$ Using regional average MMBtu per household from the same study and regional average retail fuel prices from the Alaska Division of Community and Regional Affairs fuel price survey, we estimate a regionally weighted average cost of $\$ 14$ per MMBtu for residential space heating and $\$ 18$ per MMBtu for nonresidential space heating. These figures imply that expenditures for space heating in Alaska in 2012 amounted to $\$ 1.02$ billion, or about $\$ 1,400$ per person (Table 1).

The change in HDD shown in Fig. 2 implies a population-weighted average HDD reduction of $6.7 \%$ for Alaska as a whole. Heating cost savings from this change have already been realized. Assuming an equal percentage change over the next 35 years, we estimate a \$144 million (\$98 million residential, \$46 million nonresidential) annual savings to 2050. This estimate has several limitations. Future energy prices are uncertain. The annual figure does not account for construction of new buildings or energy efficiency improvements since the 2011 (WHPacific 2012) baseline, or for potential

\footnotetext{
${ }^{2}$ One million MMBtu equals 1 trillion Btu.
}

expansion of the building stock over the next several decades. Nevertheless, it seems reasonable to project an energy cost savings by 2050 of at least $\$ 100-\$ 150$ million per year.

\section{d. High certainty, medium effect}

\section{1) WILDFIRE}

Costs of projected increases in wildfire frequency and area burned include increased firefighting costs, potential decreases in tourism, health and safety impacts, and property damage (Trainor et al. 2009). Of these, firefighting costs and property damage are the most easily quantified. Alaskan fire seasons are highly variable, but one stylized fact of change is an increasing frequency of large fire years ( $>1$ million acres burned) associated with high firefighting costs and an increased likelihood of damage to property. The most spent in 1 year fighting wildfires in Alaska was $\$ 110$ million, which was spent in 2004. Annual spending averages $\$ 10$ million per year (AKDOF 2015). A recent estimate projected an increase in wildfire suppression costs of $\$ 25$ million more per year above the 2002-13 annual average, assuming federal costs are $32 \%$ and state and local costs are $68 \%$ of total suppression costs (Melvin et al. 2017b). The cost could be higher if the footprint of human settlement expands and the geographic area designated from more active fire suppression expands accordingly.

Property damage from wildfires is also highly variable from year to year. The most expensive fire to date was the Millers Reach Fire, which destroyed 454 structures, including 200 homes in the Matanuska-Susitna Borough in 1996. Nash and Duffy (1997) estimated a total cost of the Millers Reach Fire of \$80 million (\$120 million in 2015 prices). Another fire (Sockeye Fire) in the same general area destroyed another 55 homes and heavily damaged 44 other structures in 2015. A reasonable estimate of additional property damage is $\$ 5-\$ 10$ million per year. Overall, we estimate an incremental cost of fire protection and property damage of $\$ 25-\$ 40$ million per year.

\section{2) ICE ROAD TRANSPORTATION}

Shorter seasons for ice roads both overland and across lakes and rivers raise costs for resource extraction 
activities (Hinzman et al. 2005), increase cost of living in remote communities, and impose other less tangible effects. More permanent roads and bridges are needed, or else travel and economic activity is curtailed. A 2004 report estimated the cost of ice roads on the North Slope of Alaska at $\$ 100,000$ per mile, versus as much as $\$ 2$ million per mile for a gravel road. Other estimates are higher for both transportation modes. Design and construction for the 102-mi gravel road to connect Nuiqsut to the Dalton Highway, including a bridge across the Colville River, was estimated at $\$ 350-\$ 400$ million (BLM 2004). The state of Alaska estimated \$350-\$385 million to design and construct a road of similar length to Umiat on the North Slope (Cole 2015), versus an industry cost estimate of $\$ 400,000$ per mile for ice roads (Harball 2017). An order-of-magnitude estimate of the costs of reduced surface transportation options, derived from the need to construct $50 \mathrm{mi}$ of new all-season roads per decade, would be $\$ 10-\$ 20$ million per year.

\section{3) Subsistence}

Effects on subsistence include shorter and higher-risk subsistence seasons, decline in marine mammal harvests, and effects of food security associated with increased uncertainty of access and harvest (Carothers et al. 2014; Gregory et al. 2006; Huntington et al. 2013; McNeeley 2012; Moerlein and Carothers 2012). Rural Alaskans will likely be able to adapt over time to some of these changes. Others may be unavoidable. We do not attempt to estimate a dollar value for these effects. No widely accepted method exists for valuing outputs of a nonmarket economy (Berman and Kofinas 2004). Even if such a method did exist, the cost of lost subsistence products cannot measure the cultural, social, and spiritual dimensions of subsistence livelihoods.

Table 2 summarizes the estimated economic effects of climate change categorized as relatively certain and having large or medium economic effects. Overall, direct costs we were able to quantify totaled $\$ 230-\$ 430$ million dollars per year. Most of this cost relates to prevention of damage and early replacement of infrastructure. The direct costs are offset by a savings of $\$ 100-\$ 150$ million annually from reduced space heating costs. If the added cost of repair and maintenance of private infrastructure equals that of public infrastructure, suggested here as a working hypothesis, the net cost of the items in Table 2, excluding subsistence, could reach \$340-\$700 million annually.

\section{Discussion}

Placing the economic impacts of climate change in Alaska in the context of the overall economy, the
TABLE 2. Summary of relatively certain large or medium economic effects of climate change (\$ million per year).

\begin{tabular}{ll}
\hline \hline & $\begin{array}{c}\text { Direct effect (figures enclosed } \\
\text { in parentheses indicate losses) }\end{array}$ \\
\hline $\begin{array}{l}\text { Maintenance and repair } \\
\text { of public infrastructure } \\
\text { Maintenance and repair } \\
\text { of private infrastructure } \\
\begin{array}{l}\text { Infrastructure protection } \\
\text { and community relocation }\end{array}\end{array}$ & \multicolumn{1}{|}{ Not estimated } \\
$\begin{array}{l}\text { Change in space heating } \\
\text { requirements }\end{array}$ & $(\$ 50-\$ 100)$ \\
$\begin{array}{l}\text { Wildfire fighting costs and } \\
\text { property loss }\end{array}$ & $\$ 100-\$ 150$ \\
$\begin{array}{l}\text { Ice road transportation } \\
\text { Subsistence resources } \\
\text { Total net effect }\end{array}$ & $(\$ 20-\$ 40)$ \\
\hline
\end{tabular}

${ }^{\mathrm{a}}$ The lower figures for negative effects were added to the lower estimate of the positive effect to estimate the lower figure for total net effect. The sum of the upper estimates of negative effects was added to the high figure for the positive effect to estimate the upper total net effect. In general, regional and local climate effects create the largest source of uncertainty, and the absolute values of all economic effects are correlated with regional climate outcomes.

estimated \$340-\$700 million annual net cost of the five relatively certain, relatively large, and readily quantified effects represents $0.6 \%-1.3 \%$ of Alaska's GDP in 2015 (BEA 2018). Given the concern about potentially severe climate change impacts in the Arctic raised in international assessments (ACIA 2004; Anisimov et al. 2007), one might reasonably ask why the effect is relatively modest in proportion to the state economy. There are a number of reasons. First, the five large effects included in the total figure represent only the largest and most certain of potential economic effects. Second, the figure represents a net effect, and the second-largest effect-changes in space heating costs-is positive. Excluding the space heating credit, the cost would be $1.0 \%-1.6 \%$ of the state's GDP. Perhaps most important, though, are the large regional disparities in net effects. Most of the infrastructure damage and relocation costs occur in rural Alaskan communities. Rural Alaskans also experience a bigger share of the nonquantifiable costs, including significant adverse effects on subsistence livelihoods in some regions. The majority of benefits from reduced space heating needs, on the other hand, accrue to residents of urban areas, who have on average larger homes, are more likely to work indoors, and spend more money in businesses with large commercial spaces to heat.

The uncertainties around projected impacts are large and diverse. The size of the future Alaskan population and economy is highly uncertain. Global market forces 
and national policies, such as support for rural communities, have a much greater role than climate change in determining the future of the Alaskan economy and are highly uncertain. These and other changes, such as effects on Alaska of climate change occurring elsewhere, could interact with climate change (the pace of which is also uncertain) and thereby affect the size of economic effects. Actual effects of specific environmental changes also depend on technologies available and adopted at the time, as well as on individual and collective adaptation decisions.

Gaps in the literature prevented us from evaluating many economic effects. The most important effect that needs analysis may be private infrastructure at risk from permafrost degradation, flooding, and coastal erosion. Military installations are also missing from the data on atrisk public infrastructure (Larsen et al. 2008). Better data are also needed on public and private infrastructure at risk from wildfire. Additional research is needed to assess climate change effects on key ecosystem services with potentially large economic consequences. First among these needs would be better information on long-term effects on Alaskan fisheries of increasing ocean acidification, which could interact with warming ocean temperatures. Information is also needed on potential interaction of increasing wildfire frequency with fire management costs and property damage in the wildland-urban interface.

Some information needed to project economic effects of climate change is currently unknowable. Economic effects several decades in the future depend on economic activities and the technologies that will evolve over time in association with climate trends, global markets, and government policies. Although one can reasonably project climate trends over the next several decades, one can only speculate about market, technology, and policy shifts. Effects of climate-driven changes in transportation access for extractive industries depend on size and location of future resource discoveries. Potential economic activity for Alaskan cruise ship stopovers depends on evolving global travel destination preferences. Costs of public infrastructure repair and replacement depend on government policies to support rural Arctic communities. We made our assessment assuming current conditions and trends, which represent only one of the panoply of possible scenarios.

\section{Conclusions}

We reviewed effects of climate change on ES noted in the literature, classified the effects into broad categories, and described the nature of important economic effects. The review found large negative economic effects associated with the need to protect and relocate infrastructure due to permafrost degradation, coastal erosion, and rising sea level. These negative effects were partially offset by reduced space heating costs associated with milder winter temperatures. We estimated that warming over the past several decades has already saved households, businesses, and governments at least $\$ 100$ million annually in heating costs and will likely save at least that much more over the next 35 years. Relying on the published literature, we estimated that five relatively certain, large effects that could be readily quantified would impose an average annual net cost of $\$ 340-\$ 700$ million, or $0.6 \%-1.3 \%$ of Alaska's GDP, over this same time period. This figure, however, includes only the effects that are relatively certain, near term, and readily quantified with publicly available information. The literature is incomplete in some places, such as regarding effects on private infrastructure, and much more research needs to be done to reduce the uncertainties, particularly about effects of marine environmental change. Nevertheless, these estimates suggest that climate change would impose a significant, but relatively modest, negative economic effect.

The pattern of positive and negative economic impacts includes large regional disparities. Small rural communities subject to coastal erosion, unstable permafrost, or both will face a choice between costly options of protecting infrastructure from damage and rebuilding on safer ground. Rural livelihoods including commercial fishing and subsistence face increasing uncertainty as ecosystems respond in unpredictable ways to warming and ocean acidification. Permafrost is largely absent and coastal erosion is generally much less severe in south-central Alaska and southern coastal areas, where most of the Alaskan population resides. This region will experience benefits of a milder climate with few negative consequences for infrastructure.

The disparities between net urban benefits of climate change and net rural costs are probably not unique to Alaska. However, Alaska's diverse climatic zones and uneven settlement pattern perhaps generates larger regional disparities than elsewhere. An important lesson to be drawn from the Alaska case is that climate change not only creates economic gains and losses, but also winners and losers. Policy to reduce conflict and facilitate adaptation to climate change might consider how those who gain could contribute more to financing the costly adaptation measures for those who are adversely affected.

Acknowledgments. We thank Sara Trainor, John Walsh, and Gunnar Knapp for their insightful comments. This research was supported by the National Oceanic and Atmospheric Administration's Climate Program Office [NOAA Award NA16OAR4310162Alaska Center for Climate Assessment and Policy 
(ACCAP): Science, Decision-Support, and Capacity Building for Climate Resilience in Alaska]. Its contents are solely the responsibility of the authors and do not necessarily represent the official views of NOAA.

\section{REFERENCES}

ACIA, 2004: Impacts of a warming Arctic: Arctic Climate Impact Assessment. Cambridge University Press, 140 pp., https://www. amap.no/documents/doc/impacts-of-a-warming-arctic-2004/786.

Agnew Beck Consulting, 2012: Strategic management plan Newtok to Mertarvik. State of Alaska Department of Commerce, Community, and Economic Development Rep., 38 pp., https://www.commerce.alaska.gov/web/Portals/4/pub/ Mertarvik_Strategic_Management_Plan.pdf.

AKDOF, 2015: Alaska Department of Natural Resources Division of Forestry: Annual report 2015. Alaska Department of Natural Resources, Division of Forestry Rep., 54 pp., http:// forestry.alaska.gov/Assets/pdfs/overview/2015\%20FOR \% 20web.pdf

Alessa, L., A. Kliskey, R. Busey, L. Hinzman, and D. White, 2008: Freshwater vulnerabilities and resilience on the Seward Peninsula: Integrating multiple dimensions of landscape change. Global Environ. Change, 18, 256-270, https://doi.org/ 10.1016/j.gloenvcha.2008.01.004.

Anisimov, O. A., D. G. Vaughar, T. V. Callaghan, C. Furgal, H. Marchant, T. D. Prowse, H. Vilhjálmsson, and J. E. Walsh, 2007: Polar regions (Arctic and Antarctic). Climate Change 2007: Impacts, Adaptation, and Vulnerability, M. L. Parry et al., Eds., Cambridge University Press, 653-685.

Arctic Council, 2009: Arctic marine shipping assessment 2009 report. Arctic Council Rep., 194 pp., https://www.pame.is/images/ 03_Projects/AMSA/AMSA_2009_report/AMSA_2009_Report 2nd_print.pdf.

Arent, D. J., and Coauthors, 2014: Key economic sectors and services. Climate Change 2014: Impacts, Adaptation, and Vulnerability. Part A: Global and Sectoral Aspects. C. B. Field et al., Eds., Cambridge University Press, 659-708, https://www.ipcc.ch/pdf/ assessment-report/ar5/wg2/WGIIAR5-Chap10_FINAL.pdf.

Associated Press, 2015: Alaska seeks federal money to move a village threatened by climate change. The New York Times, 3 October, https://www.nytimes.com/2015/10/04/us/alaska-seeks-federalmoney-to-move-a-village-threatened-by-climate-change.html.

Avis, C. A., A. J. Weaver, and K. J. Meissner, 2011: Reduction in areal extent of high-latitude wetlands in response to permafrost thaw. Nat. Geosci., 4, 444-448, https://doi.org/10.1038/ ngeo1160.

Azzara, A. J., H. Wang, and D. Rutherford, 2015: A 10-year projection of maritime activity in the U.S. Arctic region. International Council on Clean Transportation Rep., 73 pp., https://www.cmts.gov/downloads/CMTS_10-Year_Arctic_ Vessel_Projection_Report_1.1.15.pdf.

Barbeaux, S., K. Aydin, B. Fissel, K. Holsman, W. Palsson, K. Shotwell, Q. Yang, and S. Zador, 2017: Assessment of the Pacific cod stock in the Gulf of Alaska. Status of Stocks and Multispecies Assessments, U.S. Department of Commerce/ NOAA Rep., 189-332, https://www.afsc.noaa.gov/refm/stocks/ plan_team/2017/GOApcod.pdf.

Barber, V. A., G. P. Juday, and B. P. Finney, 2000: Reduced growth of Alaskan white spruce in the twentieth century from temperature-induced drought stress. Nature, 405, 668-673, https://doi.org/10.1038/35015049.
Barrett, K., A. D. McGuire, E. E. Hoy, and E. S. Kasischke, 2011: Potential shifts in dominant forest cover in interior Alaska driven by variations in fire severity. Ecol. Appl., 21, 2380-2396, https://doi.org/10.1890/10-0896.1.

BEA, 2018: Alaska: Personal income. Bureau of Economic Analysis Rep., 3 pp., https://apps.bea.gov/regional/bearfacts/pdf. cfm?fips $=02000 \&$ areatype $=02000 \&$ geotype $=3$.

Beck, P. S. A., and Coauthors, 2011: Changes in forest productivity across Alaska consistent with biome shift. Ecol. Lett., 14, 373 379, https://doi.org/10.1111/j.1461-0248.2011.01598.x.

Bensassi, S., J. C. Stroeve, I. Martínez-Zarzoso, and A. P. Barrett, 2016: Melting ice, growing trade? Elem. Sci. Anth., 4, 000107, https://doi.org/10.12952/journal.elementa.000107.

Berg, E. E., J. D. Henry, C. L. Fastie, A. D. De Volder, and S. M. Matsuoka, 2006: Spruce beetle outbreaks on the Kenai Peninsula, Alaska, and Kluane National Park and Reserve, Yukon Territory: Relationship to summer temperatures and regional differences in disturbance regimes. For. Ecol. Manage., 227, 219-232, https://doi.org/10.1016/j.foreco.2006.02.038.

Berman, M., and G. Kofinas, 2004: Hunting for models: Grounded and rational choice approaches to analyzing climate effects on subsistence hunting in an Arctic community. Ecol. Econ., 49, 31-46, https://doi.org/10.1016/j.ecolecon.2003.12.005.

Berthier, E., E. Schiefer, G. K. C. Clarke, B. Menounos, and F. Rémy, 2010: Contribution of Alaskan glaciers to sea-level rise derived from satellite imagery. Nat. Geosci., 3, 92-95, https://doi.org/10.1038/ngeo737.

BLM, 2004: Alpine Satellite Development Plan: Final environmental impact statement. U.S. Department of the Interior, Bureau of Land Management Rep., 1363 pp.

Brubaker, M., J. Berner, R. Chavan, and J. Warren, 2011: Climate change and health effects in Northwest Alaska. Global Health Action, 4, https://doi.org/10.3402/gha.v4i0.8445.

Calef, M. P., A. Varvak, A. D. McGuire, F. S. Chapin, and K. B. Reinhold, 2015: Recent changes in annual area burned in interior Alaska: The impact of fire management. Earth Interact., 19, 1-17, https://doi.org/10.1175/EI-D-14-0025.1.

Carothers, C., C. Brown, K. J. Moerlein, J. A. Lopez, D. B. Andersen, and B. Retherford, 2014: Measuring perceptions of climate change in northern Alaska: Pairing ethnography with cultural consensus analysis. Ecol. Soc., 19, 27, https://doi.org/ 10.5751/ES-06913-190427.

Chapin, F. S., III, and Coauthors, 2014: Alaska. Climate Change Impacts in the United States: The Third National Climate Assessment, J. M. Melillo, T. C. Richmond, and G. W. Yohe, Eds., U. S. Global Change Research Program, 514-536.

Cherry, J. E., S. Walker, N. Fresco, S. Trainor, and A. Tidwell, 2010: Impacts of climate change and variability on hydropower in Southeast Alaska: Planning for a robust energy future. Alaska Fisheries Rep., 28 pp., https://alaskafisheries. noaa.gov/sites/default/files/ccv_hydro_se.pdf.

Cheung, W. W. L., V. W. Y. Lam, J. L. Sarmiento, K. Kearney, R. Watson, and D. Pauly, 2009: Projecting global marine biodiversity impacts under climate change scenarios. Fish Fish., 10, 235-251, https://doi.org/10.1111/j.1467-2979.2008.00315.x.

Cole, D., 2015: After $\$ 35$ million, state pulls plug on Umiat road project. Anchorage Daily News, 2 January, https://www.adn. com/politics/article/after-35-million-state-pulls-plug-umiat-roadproject $/ 2015 / 01 / 02 /$.

Colt, S., S. Goldsmith, and A. Wiita, 2003: Sustainable utilities in rural Alaska: Effective management, maintenance, and operation of electric, water, sewer, bulk fuel, solid waste. Institute of Social and Economic Research, University of Alaska 
Anchorage Rep., 45 pp., https://pubs.iseralaska.org/media/ e4886fe6-2c4e-4ef7-94a0-412df1db73c7/sustainA.pdf.

, D. Dugan, and G. Fay, 2007: The regional economy of southeast Alaska. Institute of Social and Economic Research, University of Alaska Anchorage Rep., 138 pp.

Cortés-Burns, H., I. Lapina, S. Klein, M. Carlson, and L. Flagstad, 2008: Invasive plant species monitoring and control: Areas impacted by 2004 and 2005 fires in interior Alaska. Alaska Natural Heritage Program, University of Alaska Anchorage Rep., 162 pp., http://accs.uaa.alaska.edu/files/invasive-species/ Publications/2008/Invasive_Plant_Monitoring_Burned_Areas_ Dalton_Steese_and_Taylor_Highways.pdf.

DeWilde, L., and F. S. Chapin, 2006: Human impacts on the fire regime of interior Alaska: Interactions among fuels, ignition sources, and fire suppression. Ecosystems, 9, 1342-1353, https://doi.org/10.1007/s10021-006-0095-0.

Eguíluz, V. M., J. Fernández-Gracia, X. Irigoien, and C. M. Duarte, 2016: A quantitative assessment of Arctic shipping in 2010 2014. Sci. Rep., 6, 30682, https://doi.org/10.1038/srep30682.

Euskirchen, E. S., A. D. McGuire, F. S. Chapin, S. Yi, and C. C. Thompson, 2009: Changes in vegetation in northern Alaska under scenarios of climate change, 2003-2100: Implications for climate feedbacks. Ecol. Appl., 19, 1022-1043, https://doi.org/ 10.1890/08-0806.1.

Fellman, J. B., R. G. M. Spencer, P. J. Hernes, R. T. Edwards, D. V. D'Amore, and E. Hood, 2010: The impact of glacier runoff on the biodegradability and biochemical composition of terrigenous dissolved organic matter in near-shore marine ecosystems. Mar. Chem., 121, 112-122, https://doi.org/10.1016/ j.marchem.2010.03.009.

GAO, 2009: Alaska native villages: Limited progress has been made on relocating villages threatened by flooding and erosion. U.S. Government Accountability Office Rep. GAO09-551, 53 pp., https://www.gao.gov/new.items/d09551.pdf.

Goldsmith, S., 2007: The remote rural economy of Alaska. Institute of Social and Economic Research, University of Alaska Anchorage Rep., 55 pp., http://library.state.ak.us/asp/edocs/2008/ 07/ocn237803864.pdf.

_ 2010: Structural analysis of the Alaska economy: What are the drivers? Institute of Social and Economic Research, University of Alaska Anchorage Rep., 144 pp., https:// scholarworks.alaska.edu/handle/11122/4287.

Gordon, J. S., J. B. Gruver, C. G. Flint, and A. E. Luloff, 2013: Perceptions of wildfire and landscape change in the Kenai Peninsula, Alaska. Environ. Manage., 52, 807-820, https:// doi.org/10.1007/s00267-013-0127-4.

Gregory, R., L. Failing, and A. Leiserowitz, 2006: Climate change impacts, vulnerabilities, and adaptation in Northwest Alaska. Yale University Rep. 06-11, 16 pp., http://environment.yale. edu/leiserowitz/climatechange/AK_assets/FinalReport2.pdf.

Harball E., 2017: Waiting for winter: Ice roads mean the North Slope can get to work. Alaska Public Media, 17 February, https://www.alaskapublic.org/2017/02/17/ice-roads-mean-thenorth-slope-can-get-to-work/.

Hayhoe, K., J. Edmonds, R. E. Kopp, A. N. LeGrande, B. M. Sanderson, M. F. Wehner, and D. J. Wuebbles, 2017: Climate models, scenarios, and projections. Climate Science Special Report: Fourth National Climate Assessment, Vol. I, D. J. Wuebbles et al., Eds., U.S. Global Change Research Program, 133-160, https://doi.org/10.7930/J0WH2N54.

Hezel, P. J., X. Zhang, C. M. Bitz, B. P. Kelly, and F. Massonnet, 2012: Projected decline in spring snow depth on Arctic sea ice caused by progressively later autumn open ocean freeze-up this century. Geophys. Res. Lett., 39, L17505, https://doi.org/ 10.1029/2012GL052794.

Hicke, J. A., M. C. Johnson, J. L. Hayes, and H. K. Preisler, 2012: Effects of bark beetle-caused tree mortality on wildfire. For. Ecol. Manage., 271, 81-90, https://doi.org/10.1016/ j.foreco.2012.02.005.

Hinzman, L. D., and Coauthors, 2005: Evidence and implications of recent climate change in northern Alaska and other Arctic regions. Climatic Change, 72, 251-298, https://doi.org/10.1007/ s10584-005-5352-2.

Hong, E., R. Perkins, and S. Trainor, 2014: Thaw settlement hazard of permafrost related to climate warming in Alaska. Arctic, 67, 93-103, https://doi.org/10.14430/arctic4368.

Hood, E., and D. Scott, 2008: Riverine organic matter and nutrients in southeast Alaska affected by glacial coverage. Nat. Geosci., 1, 583-587, https://doi.org/10.1038/ngeo280.

—, J. Fellman, R. G. M. Spencer, P. J. Hernes, R. Edwards, D. D'Amore, and D. Scott, 2009: Glaciers as a source of ancient and labile organic matter to the marine environment. Nature, 462, 1044-1047, https://doi.org/10.1038/nature08580.

Hope, C., and K. Schaefer, 2016: Economic impacts of carbon dioxide and methane released from thawing permafrost. Nat. Climate Change, 6, 56-59, https://doi.org/10.1038/nclimate2807.

Hovelsrud, G. K., B. Poppel, B. van Oort, and J. D. Reist, 2011: Arctic societies, cultures, and peoples in a changing cryosphere. Ambio, 40, 100-110, https://doi.org/10.1007/s13280011-0219-4.

Huntington, H. P., and Coauthors, 2013: Local and traditional knowledge regarding the Bering Sea ecosystem: Selected results from five indigenous communities. Deep-Sea Res. II, 94, 323-332, https://doi.org/10.1016/j.dsr2.2013.04.025.

— safe shipping in Bering Strait. Mar. Policy, 51,119-127, https:// doi.org/10.1016/j.marpol.2014.07.027.

_, L. T. Quakenbush, and M. Nelson, 2016: Effects of changing sea ice on marine mammals and subsistence hunters in northern Alaska from traditional knowledge interviews. Biol. Lett., 12, 20160198, https://doi.org/10.1098/rsbl.2016.0198.

IPCC, 2007: Climate Change 2007: Impacts, Adaptation and Vulnerability. Cambridge University Press, 976 pp.

Jacob, T., J. Wahr, W. T. Pfeffer, and S. Swenson, 2012: Recent contributions of glaciers and ice caps to sea level rise. Nature, 482, 514-518, https://doi.org/10.1038/nature10847.

Jafarov, E. E., S. S. Marchenko, and V. E. Romanovsky, 2012: Numerical modeling of permafrost dynamics in Alaska using a high spatial resolution dataset. Cryosphere, 6, 613-624, https:// doi.org/10.5194/tc-6-613-2012.

Jia, G. S. J., H. E. Epstein, and D. A. Walker, 2003: Greening of arctic Alaska, 1981-2001. Geophys. Res. Lett., 30, 2067, https:// doi.org/10.1029/2003GL018268.

Johnstone, J. F., T. S. Rupp, M. Olson, and D. Verbyla, 2011: Modeling impacts of fire severity on successional trajectories and future fire behavior in Alaskan boreal forests. Landscape Ecol., 26, 487-500, https://doi.org/10.1007/s10980-0119574-6.

Jolly, W. M., R. Parsons, J. M. Varner, B. W. Butler, K. C. Ryan, and C. L. Gucker, 2012: Do mountain pine beetle outbreaks change the probability of active crown fire in lodgepole pine forests? Comment. Ecology, 93, 941-946.

Juday, G. P., and Coauthors, 2005: Forests, land management, and agriculture. Arctic Climate Impact Assessment 2004, ACIA, 781-862, http://www.acia.uaf.edu/PDFs/ACIA_ Science_Chapters_Final/ACIA_Ch14_Final.pdf. 
Kelly, R., M. L. Chipman, P. E. Higuera, I. Stefanova, L. B. Brubaker, and F. S. Hu, 2013: Recent burning of boreal forests exceeds fire regime limits of the past 10,000 years. Proc. Natl. Acad. Sci. USA, 110, 13 055-13 060, https://doi.org/10.1073/pnas.1305069110.

Kofinas, G. P., and Coauthors, 2010: Resilience of Athabascan subsistence systems to interior Alaska's changing climate. Can. J. For. Res., 40, 1347-1359, https://doi.org/10.1139/X10-108.

Lapina, I., and M. L. Carlson, 2004: Non-native plant species of Susitna, Matanuska, and Copper River basins: Summary of survey findings and recommendations for control actions. Alaska Natural Heritage Program, Environment and Natural Resources Institute, University of Alaska Anchorage Rep., 62 pp., http://aknhp.uaa.alaska.edu/botany/akepic/publications/.

Larsen, J. N., and G. Fondahl, Eds., 2014: Arctic human development report. Nordic Council of Ministers Rep., 500 pp., http://norden. diva-portal.org/smash/get/diva2:788965/FULLTEXT03.pdf.

— , and Coauthors, 2014: Polar regions. Climate Change 2014: Impacts, Adaptation, and Vulnerability, C. B. Field et al., Eds. Cambridge University Press, 1567-1612.

Larsen, P. H., S. Goldsmith, O. Smith, M. L. Wilson, K. Strzepek, P. Chinowsky, and B. Saylor, 2008: Estimating future costs for Alaska public infrastructure at risk from climate change. Global Environ. Change, 18, 442-457, https://doi.org/10.1016/ j.gloenvcha.2008.03.005.

Markon, C. J., S. F. Trainor, and F. S. Chapin III, Eds., 2012: The United States National Climate Assessment-Alaska technical regional report. U.S. Geological Survey Circular 1379, 166 pp., https://pubs.usgs.gov/circ/1379/pdf/circ1379.pdf.

Mathis, J. T., J. N. Cross, N. Monacci, R. A. Feely, and P. Stabeno, 2014: Evidence of prolonged aragonite undersaturations in the bottom waters of the southern Bering Sea shelf from autonomous sensors. Deep-Sea Res. II, 109, 125-133, https://doi.org/ 10.1016/j.dsr2.2013.07.019.

McDowell, 2016: Economic impact of Alaska's visitor industry: 2014-15 update. Alaska Department of Commerce, Community, and Economic Development Rep., 11 pp., http:// www.alaskatia.org/Research/Visitor\%20Impacts\%202016\% 20update\%204_15_16.pdf.

McNeeley, S. M., 2012: Examining barriers and opportunities for sustainable adaptation to climate change in interior Alaska. Climatic Change, 111, 835-857, https://doi.org/10.1007/ s10584-011-0158-x.

Melvin, A. M., and Coauthors, 2017a: Climate change damages to Alaska public infrastructure and the economics of proactive adaptation. Proc. Natl. Acad. Sci. USA, 114, E122-E131, https://doi.org/10.1073/pnas.1611056113.

_ , J. Murray, B. Boehlert, J. A. Martinich, L. Rennels, and T. S. Rupp, 2017b: Estimating wildfire response costs in Alaska's changing climate. Climatic Change, 141, 783-795, https://doi. org/10.1007/s10584-017-1923-2.

Meter, K., and M. Phillips Goldenberg, 2014: Building food security in Alaska. Alaska Department of Health and Social Services Rep., 180 pp., http://www.crcworks.org/akfood.pdf.

Moerlein, K. J., and C. Carothers, 2012: Total environment of change: Impacts of climate change and social transitions on subsistence fisheries in northwest Alaska. Ecol. Soc., 17, 10, https://doi.org/10.5751/ES-04543-170110.

Nash, C. E., and D. Duffy, 1997: Miller's reach fire strategic economic recovery plan: Final revised plan. Matanuska-Susitna Borough Department of Planning Rep.

National Research Council, 2014: The Arctic in the Anthropocene: Emerging Research Questions. The National Academies Press, 224 pp., https://doi.org/10.17226/18726.
Nelson, J. L., E. S. Zavaleta, and F. S. Chapin, 2008: Boreal fire effects on subsistence resources in Alaska and adjacent Canada. Ecosystems, 11, 156-171, https://doi.org/10.1007/ s10021-007-9114-z.

Nicholls, R. J., P. P. Wong, V. R. Burkett, J. O. Codignotto, J. E. Hay, R. F. McLean, S. Ragoonaden, and C. D. Woodroffe, 2007: Coastal systems and low-lying areas. Climate Change 2007: Impacts, Adaptation, and Vulnerability, M. L. Parry et al., Eds., Cambridge University Press, 315-356.

Pisaric, M. F. J., J. R. Thienpont, S. V. Kokelj, H. Nesbitt, T. C. Lantz, S. Solomon, and J. P. Smol, 2011: Impacts of a recent storm surge on an Arctic delta ecosystem examined in the context of the last millennium. Proc. Natl. Acad. Sci. USA, 108, 8960-8965, https://doi.org/10.1073/pnas.1018527108.

Raynolds, M. K., and Coauthors, 2014: Cumulative geoecological effects of 62 years of infrastructure and climate change in ice-rich permafrost landscapes, Prudhoe Bay Oilfield, Alaska. Global Change Biol., 20, 1211-1224, https://doi.org/10.1111/gcb.12500.

Reid, W., and Coauthors 2005: Ecosystems and Human Well-Being: Synthesis. Island Press, 155 pp., https://www.millenniumassessment. org/documents/document.356.aspx.pdf.

Reimchen, D., G. Doré, D. Fortier, B. Stanley, and R. Walsh, 2009: Cost and constructability of permafrost test sections along the Alaska Highway, Yukon. Transportation Association of Canada Rep., 20 pp., http://conf.tac-atc.ca/english/resourcecentre/ readingroom/conference/conf2009/pdf/Reimchen.pdf

Romanovsky, V., S. Marchenko, R. Daanen, D. Sergeev, and D. Walker, 2008: Soil climate and frost heave along the permafrost/ecological North American Arctic transect. Ninth Int. Conf. on Permafrost, Fairbanks, AK, University of Alaska Fairbanks, 6 pp.

Royer, T. C., and C. E. Grosch, 2006: Ocean warming and freshening in the northern Gulf of Alaska. Geophys. Res. Lett., 33, L16605, https://doi.org/10.1029/2006GL026767.

Schroth, A. W., J. Crusius, F. Chever, B. C. Bostick, and O. J. Rouxel, 2011: Glacial influence on the geochemistry of riverine iron fluxes to the Gulf of Alaska and effects of deglaciation. Geophys. Res. Lett., 38, L16605, https://doi.org/ 10.1029/2011GL048367.

Scott, J. M., and Coauthors, 2008: National wildlife refuges. Preliminary Review of Adaptation Options for Climate-Sensitive Ecosystems and Resources, S. H. Julius and J. M. West, Eds., U.S. Environmental Protection Agency Rep., 5-1-5-100.

Smith, L. C., and S. R. Stephenson, 2013: New trans-Arctic shipping routes navigable by midcentury. Proc. Natl. Acad. Sci. USA, 110, E1191-E1195, https://doi.org/10.1073/pnas.1214212110.

Stabeno, P. J., G. L. Hunt Jr., J. M. Napp, and J. D. Schumacher, 2005: Physical forcing of ecosystem dynamics on the Bering Sea shelf. The Sea, Vol. 14, A. R. Robinson and P. H. Brink, Eds., Harvard University Press, 1177-1212.

State of Alaska, 2010: Alaska's climate change strategy: Addressing impacts in Alaska. Adaptation Advisory Group to the Alaska Climate Change Sub-Cabinet Rep., 94 pp., http://dev. cakex.org/sites/default/files/Alaska.pdf.

Stewart, B. C., K. E. Kunkel, L. E. Stevens, L. Sun, and J. E. Walsh, 2013: Regional climate trends and scenarios for the U.S. National Climate Assessment. Part 7: Climate of Alaska. NOAA Tech. Rep. NESDIS 142-7, 60 pp., https:// scenarios.globalchange.gov/sites/default/files/NOAA_NESDIS_ Tech_Report_142-7-Climate_of_Alaska_0.pdf.

Sturm, M., C. Racine, and K. Tape, 2001: Increasing shrub abundance in the Arctic. Nature, 411, 546-547, https://doi.org/ $10.1038 / 35079180$ 
Taylor, P. C., W. Maslowski, J. Perlwitz, and D. J. Wuebbles, 2017: Arctic changes and their effects on Alaska and the rest of the United States. Climate Science Special Report: Fourth National Climate Assessment, Volume I, D. J. Wuebbles et al., Eds., U.S. Global Change Research Program Rep., 303-332, https://doi.org/10.7930/J00863GK.

Terenzi, J., M. T. Jorgenson, and C. R. Ely, 2014: Storm-surge flooding on the Yukon-Kuskokwim Delta, Alaska. Arctic, 67, 360-374, https://doi.org/10.14430/arctic4403.

Trainor, S. F., and Coauthors, 2009: Vulnerability and adaptation to climate-related fire impacts in rural and urban interior Alaska. Polar Res., 28, 100-118, https://doi.org/10.1111/j.17518369.2009.00101.x.

United Nations, 1997: Glossary of environment statistics. Department for Economic and Social Information and Policy Analysis Rep. F/67, 96 pp., https://unstats.un.org/unsd/publication/ SeriesF/SeriesF_67E.pdf.

USACE, 2008a: Newtok Evacuation Center: Mertarvik, Nelson Island, Alaska. U.S. Army Corps of Engineers Rep., 64 pp., https://www.commerce.alaska.gov/web/portals/4/pub/ 2008_newtok_evacuation_center_ea_\&_fonsi.pdf.

2008b: Alaska baseline erosion assessment. Erosion information paper: Koyukuk, Alaska. U.S. Army Corps of Engineers Rep., 4 pp., http://www.poa.usace.army.mil/Portals/34/ docs/civilworks/BEA/Koyukuk_Final\%20Report.pdf.

_- 2009: Alaska baseline erosion assessment. Study findings and technical report. U.S. Army Corps of Engineers Tech. Rep., 65 pp., http://www.poa.usace.army.mil/Portals/34/docs/civilworks/ BEA/AlaskaBaselineErosionAssessmentBEAMainReport.pdf.

USDA, 2017: Local food directories: National farmers market directory. USDA, accessed 29 November 2018, https://www. ams.usda.gov/local-food-directories/farmersmarkets.

USEPA, 2017: Multi-model framework for quantitative sectoral impacts analysis: A technical report for the Fourth National Climate Assessment. U.S. Environmental Protection Agency
Tech. Rep., 277 pp., https://cfpub.epa.gov/si/si_public_file_ download.cfm?p_download_id=537327\&Lab=OAP.

Vermaire, J. C., M. F. J. Pisaric, J. R. Thienpont, C. J. C. Mustaphi, S. V. Kokelj, and J. P. Smol, 2013: Arctic climate warming and sea ice declines lead to increased storm surge activity. Geophys. Res. Lett., 40, 1386-1390, https://doi.org/10.1002/grl.50191.

Walsh, J., and Coauthors, 2014: Our changing climate. Climate Change Impacts in the United States: The Third National Climate Assessment, J. M. Melillo, T. T. C. Richmond, and G. W. Yohe, Eds., U.S. Global Change Research Program Rep., 19-67.

Wendler, G., and M. Shulski, 2009: A century of climate change for Fairbanks, Alaska. Arctic, 62, 295-300, https://doi.org/ 10.14430/arctic149.

— L. Chen, and B. Moore, 2012: The first decade of the new century: A cooling trend for most of Alaska. Open Atmos. Sci. J., 6, 111-116, https://doi.org/10.2174/1874282301206010111.

_ B. Boore, and K. Galloway, 2014: Strong temperature increase and shrinking sea ice in Arctic Alaska. Open Atmos. Sci. J., 8, 7-15, https://doi.org/10.2174/1874282301408010007.

White, D. M., S. C. Gerlach, P. Loring, A. C. Tidwell, and M. C. Chambers, 2007: Food and water security in a changing arctic climate. Environ. Res. Lett., 2, 045018, https://doi.org/10.1088/ 1748-9326/2/4/045018

WHPacific, 2012: Alaska Energy Authority end use study: 2012. WHPacific Rep., 151 pp., http://www.akenergyauthority.org/Content/ Efficiency/EndUse/Documents/AlaskaEndUseStudy2012.pdf.

Wolfe, R. J., and R. J. Walker, 1987: Subsistence economies in Alaska: Productivity, geography, and development impacts. Arctic Anthropol., 24, 56-81.

Wolken, J. M., and Coauthors, 2011: Evidence and implications of recent and projected climate change in Alaska's forest ecosystems. Ecosphere, 2, 1-35, https://doi.org/10.1890/ES11-00288.1.

Yu, G. M., Z. Schwartz, and J. E. Walsh, 2009: Effects of climate change on the seasonality of weather for tourism in Alaska. Arctic, 62, 443-457, https://doi.org/10.14430/arctic175. 